\title{
ENTGEGNUNG AUF WUBS-MROZEWICZ UND BURKHARDT, DAS BERGENER KONTOR 1 UND $2^{*}$
}

\author{
von Arnved Nedkvitne
}

In HGbll. from 2013 I published an article entitled „Das Bergener Kontor im Mittelalter". In its first version it had no historiography of earlier research because $I$ felt uncomfortable about evaluating the work of other historians who were still alive and compare their work to my own. But one of the Gutachter strongly recommended that an historiography should be added, and the editor agreed. I consented on the condition that I was allowed to give my honest opinion. As I had foreseen, two of the historians did not think I gave them sufficient honour, and the editor permitted them to write Entgegnungen. I was not offered the opportunity to give a final answer in the same issue, but here it comes one year later.

I claimed that the main conclusions in the PhDs of Justyna WubsMrozewicz and Mike Burkhardt were not new for those who could read Norwegian and knew Friedrich Bruns' book about Die Liibecker Bergenfahrer und ihre Chronistik. They did not compare their own results to those of their predecessors, therefore this lack of originality is only visible to those who know earlier research and can do this comparison on their own.

Wubs-Mrozewicz uses most of her Entgegnung to repeat in brief what she did in her PhD-thesis. But she still does not answer the question discussed here, what is new about it? This can only be answered by comparing to what Johan Schreiner' and myself ${ }^{2}$ wrote on the relations bet-

\footnotetext{
* Anmerkung der Redaktion: Wegen eines Missverständnisses konnte Herr Nedkvitne sejne Gegendarstellung nicht bereits im vorhergehenden Band veröffentlichen. wie es den akademischen Gepflogenheiten entsprochen hätte. Sie folgt hier ein Jahr später. Hiermit ist diese Diskussion in den Hansischen Geschichtsblättern beendet.

' Johan SCHREINER. Hanseatene og Norge i det 16. århundre, Oslo 1941, pp. 34-43. $48-56,108-109,126,154-155,168.220-221.226-235$. cf. the index where more references are found.

2 Arnved NEDKVITNE. Utenrikshandelen fra det vestafjelske Norge 1100-1600, thesis for the degree of Dr. Philos, University of Bergen 1983, pp. 53-56, 136-148, 152-163. 171, 254. 262-263. 265-267. 274-276, 319-335; relevant entries in the index: "Zuidersjøbyene"
} 
ween Zuiderzee. Holland and Lübeck merchants in Bergen, and this is not done.

She also claims that "Die von mir gestellten sozialhistorischen Fragen unterscheiden sich deutlich von den wirtschaftlichen Untersuchungen A. Nedkvitnes." In reality the major part of her PhD describes political, judicial, and economic developments in Bergen, the social relations are only a minor part of it. On the previous page she writes correctly that the subject of her PhD “... wurden auf mehreren Ebenen untersucht: Privilegien und Politik, Verwaltung, Regeln und Recht, Handel mit verschiedenen Gütern und Konfliktlösung ". ${ }^{3}$ Wubs-Mrozewicz, Schreiner and myself have examined the relationship between the Zuiderzee towns, Holland and Lübeck on the political, judicial, economic and social levels. If she claims that her way of analysing and combining these levels have produced new and original results, she has to show this by comparing to earlier research.

She claims that unprinted sources have made it possible for her to arrive at new results. ${ }^{4}$ It is correct that such sources have made it possible for her to present the interesting post-Reformation case against Hinrik van Hasselt 1542-1544. It does not appear from text or footnotes which other unprinted sources have permitted new insights. She also claims to have used "a larger corpus of source material than has been used in previous research". This claim should be verified.

Accepted methodology requires authors to discuss through comparisons where their main results repeat or confirm earlier research and where their results are new. The author can not simply claim to be original, and leave the verification or falsification of that claim to others. This holds true for Mike Burkhardt as well as Justyna Wubs-Mrozewicz.

Burkhardt makes an explicit claim to have corrected earlier research on one major point. Friedrich Bruns showed that what he called "Bergenfahrer" rarely belonged to the leading families in Lübeck. "Von Haus aus

(46 entries), "Kampen" (43 entries), "Deventer" (41 entries), "Holland/Nederland" (90) entries) and "Amsterdam" (24 entries). The revised edition, Arnved NEDKVITNE. The German Hansa and Bergen, Böhlau Verlag, Köln 2014. pp. 85-87, 96-105, 197-220, 350. 358-360, 370-371, 404, 46.3-474; relevant entries in the index: "Zuiderze towns. group of Hansa towns" (34 entries), "Zuiderzee towns" conflicts with Bergen Kontor" (23 entries), "Zuiderzee merchants as winter residents" (4 entries). See also "Kampen", "Deventer", "Amsterdam" and "Holland, province in present day Netherlands".

"Justyna WUBS-MROZEWICZ, "Entgegnung auf Nedkvitne. Das Bergener Kontor", in: HGbll. 131, 2013. pp. 193-194.

${ }^{4}$ Justyna WUBS-MROZEWICZ. Traders. Ties and Tensions. The Interaction of Lubeckers, Overijsslers and Hollanders in Late Medieval Bergen. Hilversum 20(08, pp. 14, 21 and 25 .

Ibid. pp. 236-243.

${ }^{6}$ Ihid. n. 245. 
gehörten die Lübecker Bergenfahrer durchweg den ärmeren Bevölkerungsschichten an", „Ihren kleinen Anfängen entsprechend, haben sich die Bergenfahrer im allgemeinen zu nur mässigem Wohlstande aufgeschwungen". ${ }^{3}$

Mike Burkhardt holds a different opinion of what he calls "Bergenfahrer". "Im Gegensatz zu den Aussagen Bruns", die in allen Aufsätzen und Büchern ... kritiklos übernommen wurden, waren die Bergenfahrer keineswegs cine wenig angesehene Gruppe unter der städtischen Kaufmannschaft." Is Burkhardt's revision of Bruns real, or do they merely use the word "Bergenfahrer" differently?

In his Entgegnung Burkhardt does not distinguish clearly between "Bergenfahrer" as an analytical concept which has to be defined by the historian who uses it, and "Bergenfahrer" as used by Hansa merchants and their contemporaries, the latter is an empirical question and has to be examined empirically. In our context it is "Bergenfahrer" as analytical concept which is up for discussion.

Bruns did not define the word, but from the context can be seen that he meant a member of the Bergenfahrer guild in Lübeck, and he assumed that all of them owned a firm with houses in Bergen or worked or had worked in such a firm. He also included citizens of other Hansa towns who owned firms and houses in Bergen. In my thesis I distinguished between winter residents (Wintersitzer) and summer guests (Sommergäste), Bruns used the word "Bergenfahrer" about winter residents only.

Burchardt claims that he has "eine neue Definition des Begriffs Bergenfahrer in den wissenschaftlichen Diskurs eingebracht". " This definition is to be found in the introduction to his "Prosopographischer Katalog". 1" His first category of Bergenfahrer is an "im Bergenhandel nachgewiesener Kaufmann", which means that he includes both winter residents and summer guests. A merchant who is mentioned in a source as trading to Bergen once, is categorised by Burkhardt as "Bergenfahrer", even if his main interest was in Flanders." He also has a second category of ,mit großer Wahrscheinlichkeit im Bergenhandel aktiver Kaufmann." In practice most

\footnotetext{
${ }^{7}$ Friedrich BRUNS, Die Lübecker Bergenfahrer und ihre Chronistik, Berlin 1900 (Hansische Geschichtsquellen. Neue Folge II), Berlin 190(), pp. CXLII-CXLIII.

${ }^{8}$ Mike BURKHARDT. Der hansische Bergenhandel im Spätmittelalter. Handel - Kaufleute - Netzwerke, Köln 20(0), p. 356.

"Mike BURKHARDT. "Entgegnung auf Nedkvitne, Das Bergener Kontor". in: HGbll. 131, 2013, pp. 189-192. here p. 192.

"BURKHARDT, Der hansische Bergenhandel (as in footnote 8). Prosopographischer Katalog on CD. pp. 2-3.

"A distinction between winter residents and summer guests would for example have been useful at BURKHARDT, Der hansische Bergenhandel (as in footnote 8). pp. 76-78.
} 
of them had some kind of economic or other connections to Bergenfahrer of the first category. If merchants of the second category traded to Bergen at all, it is highly likely that it was as summer guests. It then becomes obscure what Burkhardt's "Bergenfahrer" have in common, apart from those in the first category having at least once in their lifetime shipped a consignment of goods to or from Bergen. ${ }^{12}$

Burkhardt in his PhD thesis uses the word "Bergenfahrer" differently from Bruns without realising that he does so. He therefore nowhere in his $\mathrm{PhD}$ discusses which consequences the divergent use of the word has for his conclusions. Burkhardt thinks that he has verified new theories about the "Bergenfahrer's" social status when the reality is that he uses the word about a different social group. In my thesis I made a point of using the two analytical concepts "winter residents" and "summer guests" wherever this distinction was significant.

Burkhardt introduces what he calls "Nedkvitnes Definition", and in his own words "spricht mir Nedkvitne das Recht ab, einen andreren Bergenfahrerbegriff zu verwenden". ${ }^{13}$ He does not tell where he has read this. An analytical concept has to be given a definition which is fruitful in the relevant study, in the sense that it makes possible a verification of relevant hypotheses. It is methodologically unproblematic that two authors define the same word differently. But when comparing one's own results to those of another author who gives the same analytical concept a different meaning, the consequences of this difference have to be discussed.

Bruns counted 13 "Bergenfahrer" as "Ratsherren" 1363-1544 and Burkhardt 27 1350-1511. The difference is explained by the fact that Burkhardt's group is larger and different. But Bruns and Burkhardt agree that the number of "Bergenfahrer" in Lübeck's urban council (Rat) was highest ca. $1360-1500 .{ }^{14}$ As shown in my thesis this was the period when European stockfish prices were most favourable, which benefitted both winter residents and summer guests. ${ }^{15}$ This period saw the flowering (Bliitezeit) of the Hansa merchants in Bergen.

To conclude this discussion, Burkhardt in his $\mathrm{PhD}$ thesis has not falsified Bruns' theory about the social status of the winter residents in Lübeck. I hope a future MA or PhD student will find it interesting and

\footnotetext{
${ }^{12}$ He includes both category one and two in his table "Bergenfahrer im Rat der Stadt Lübeck 1350-1510" (ibid. pp. 271-272). It is not always clear whether his second category is included in other tables and figures.

${ }^{13}$ BURKHARDT, Entgegnung (as in footnote 9), p. 189.

${ }^{14}$ BRUNS, Bergenfahrer (as in footnote 7), p. CXLIV; BURKHARDT, Der hansische Bergenhandel (as in footnote 8), pp. 78 and 272.

${ }^{15}$ NEDKVITNE, Utenrikshandelen (as in footnote 2) and NEDKVITNE. The German Hansa (as in fontnote 2 ) in both rehanter VI
} 
challenging to make a methodologically correct study of this problem which is important for the history of the Hanseatic Bergen trade.

Burkhardt writes that „Nedkvitnes Dissertation“ for him was „schwer zu erhalten" when he wrote his $\mathrm{PhD}$. He studied in Copenhagen and there it was available at Det Kongelige Bibliotek. ${ }^{16}$ In Burkhardt's words I also refused, "... mit mir in einen wissenschaftlichen Austausch zu treten". 17 The reality behind this is that he 06.09 .2002 sent an e-mail where he asked if I could help him get a scholarship in Oslo to write a PhD-thesis about the Hansa and Bergen. At that time I was responsible for ca $20 \mathrm{MA}-\mathrm{stu}-$ dents and three PhD-students in Oslo, several of whom needed similar help, and I had to give priority to them. After that I had no contacts with him, and he has never asked me to read his manuscripts. I find Burkhardt's way of describing the realities of university life in Germany and Norway strange. Burkhardt makes several other vaguely formulated claims and complaints, and those who are more interested in Burkhardt. Bruns and Nedkvitne than in the German Hansa and Bergen are of course free to compare our texts.

\footnotetext{
${ }^{16}$ BURKHARDT, Entgegnung (as in footnote 9), p. 191; cf. BURKHARDT. Der hansische Bergenhandel (as in footnote 8), pp. 19-20.

${ }^{17}$ BURKHARDT. Entgegnung (as in footnote 9), p. 191.
} 